\title{
Corporate Social Responsibility and Corporate Sustainable Development-Evidence from Listed Tourism and Commerce Companies
}

\author{
Guo-Bao XIONG ${ }^{1, a}$, Ming ZHOU ${ }^{2}, \mathrm{Ye} \mathrm{LE}^{1}, \mathrm{Yu}_{\mathrm{ZHAO}}{ }^{1}$ and Ru-Hui MA ${ }^{2, *}$ \\ ${ }^{1}$ Center for resources and Environmental Economics,East China Institute of Technology, \\ Nanchang, China,330013 \\ ${ }^{2}$ Center of Geological Resource Economics and Management Research,East China Institute of \\ Technology, Nanchang,China,330013 \\ *Corresponding author:axxh8399@163.com
}

\begin{abstract}
Keywords: Corporate Social Responsibility; Sustainable Development; Tourism and Commerce Companies
\end{abstract}

\begin{abstract}
The starting point of this paper is the fulfillment of corporate social responsibility of listed tourism and commerce companies in China. This paper goes on to build a corporate sustainable development index system in terms of operating capacity, solvency capacity and development capacity; and uses empirical data of 69 listed companies from 2010-2012 to test the impact of fulfillment of social responsibility on corporate sustainable development. The study finds that for listed tourism and commerce companies, the fulfillment of corporate social responsibility to employees, customers, investors, suppliers, government and other stakeholders has little effect on the sustainable development at present; but will have a significant impact on the companies' future sustainable development. In the long run, companies can achieve sustainable development only if they can deal well with the interests of all stakeholders.
\end{abstract}

\section{Introduction}

For a long time, corporate social responsibility (CSR) has been a hot issue among researchers. To date, the study on corporate social responsibility has been focused on the concept of corporate social responsibility and the correlations between CSR and corporate economic performance and other aspects. But since the 1970s, with the growing attention on safety, environmental protection, health and with the promotion of the concept of sustainable development, scholars have started to incorporate sustainable development into the research of corporate social responsibility as a new research direction. Practices at home and abroad have shown that by actively fulfilling their social responsibility, the companies not only can get good brand image and social reputation, but also can achieve long-term economic benefits and promote and facilitate the sustainable development. In this paper, by taking listed tourism and commerce companies as samples, we use the empirical data of 69 listed companies from 2010 to 2012 to test the impact of fulfilling corporate social responsibility to employees, customers, investors, suppliers, government and other stakeholders on corporate sustainable development.

\section{Literature Review}

By reviewing literature at home and abroad, we can see that research on the relationship between corporate social responsibility and corporate performance has made a lot of achievements. Through their analyses, scholars represented by Dijken (2007) conclude that there is a positive correlation between CSR and business performance [1]. But other scholars believe that corporate social responsibility will have a negative impact on business performance in the short term (Brammer, 2006) [2]. Different scholars use different indicators and factors in their empirical analyses, leading to big differences in their results. The researches mentioned above are mainly focused on the relationship between corporate social responsibility and corporate short-term performance, but there has been little research on the relationship between corporate social responsibility and corporate long-term performance, i.e. corporate sustainable development. Very few scholars have tried to incorporate CSR, corporate performance and corporate sustainable development into one research 
framework (Freedman, 1982)[3]. The findings of Chinese scholars Wang Jianqiong and Hou Tingting (2009) show that fulfillment of corporate responsibility to employees is positively correlated to corporate sustainable development, but this only partially reflects that fulfillment of corporate social responsibility can promote corporate sustainable development:[4].

In modern society, enterprises are just a subsystem of the social system, and they must integrate into the bigger social system so as to achieve better development. Through their experiments, Brown and Dacin (1997) verifies that fulfillment of corporate social responsibility has a positive influence on the customers, which will help the customers to make positive assessments on the company, thus helping to promote corporate sustainable development [5]. Through the empirical example of a Brazilian company, Carla (2007) proves that corporate social responsibility plays an important role to promote corporate sustainable development [6]. Chinese scholar Shao Wenhua's study (2006)suggests that corporate social responsibility has its driving, binding and propelling forces on sustainable development[7]. Therefore, corporate social responsibility is an important variable to influence corporate sustainable development; and it is closely related to the survival and development of companies, and not only will help to create a favorable external environment, but also will help to enhance the companies' social image and reputation and promote corporate sustainable development (Li Peilin, 2006) [8]. Corporate sustainable development is an important part of fulfillment of corporate social responsibility, and corporate social responsibility plays an active role in promoting sustainable development, to a certain extent making up for the shortcomings of market regulation and government intervention (Wang Faming, 2005)[9], and is the third force promoting sustainable economic and social development.

\section{Research Hypotheses}

As an important part of the companies and society, employees play a vital role in the survival and development of the companies: not only are they the driving force of corporate long-term development, but the long-term survival and development of enterprises also rely on their initiative and creativity. Companies should provide their employees with good benefits and health care, and that not only will increase employees' loyalty to the company, but also will directly affect business performance. If the employees appreciate the value of their own position in the enterprises, and enterprises also feel the effect of the efforts of their employees' on corporate sustainable development, then the enterprises and employees can reach harmonious consensus. Thus we propose:

Hypothesis 1: the more attention the company pays to employees' interests, the stronger the capacity for corporate sustainable development is.

Customers are at the core of a company's services, and customer satisfaction is the source of corporate value. Companies should keep on understanding customer needs and use all methods to ensure customer satisfaction in order to maintain a competitive advantage in the market competition. Companies should provide customers with value-added services, not only to win the trust and praise of customers, but also to get recognition from the society and enhance corporate reputation. Thus we propose: Hypothesis 2: the more attention the company pays to its customers' interests, the stronger the capacity for corporate sustainable development is.

Investors are the most important and most influential supporters to the companies, and they play a key role in improving the companies' core competitiveness. In highly competitive market conditions, the listed companies should actively establish good communicative and trusting relationships with existing and potential investors so as to seek long-term development. At the same time, the companies should provide investors with higher long-term returns and effectively protect the legitimate rights and interests of investors. This will not only help to broaden the financing channels for the companies and expand the reproduction capacity, but also will help to give full play to the supervisory role of investors and improve corporate governance. Thus we propose:

Hypothesis 3: the more attention the company pays to its investors' interests, the stronger the capacity for corporate sustainable development is. 
Tourism and commerce companies belong to the service-oriented business, and the provision of their products and guarantee of product quality all rely on the cordial cooperation between the company and its suppliers. Only when the company and its suppliers maintain good cooperative relations, can they promote their values mutually and enhance their sustainable development capacity, whereby ultimately winning the market competitive advantage. Thus we propose Hypothesis 4: the more attention the company pays to its suppliers' interests, the stronger the capacity for corporate sustainable development is.

With public interest as objectives of its service, the government is the manager of social wealth and plays a huge role in promoting and supervising the process of building a harmonious society. The companies, as an important part of society, are the main players in market activities. The companies should strictly follow the laws of the market, pay taxes, fulfill due social responsibilities; and this will not only help the government safeguard the public interest of the society and coordinate the economic interests of all sectors of society to promote greater social justice, but also will help to create a favorable external environment for the long-term development of enterprises, which is essential for the long-term stability and development of enterprises. Thus we propose Hypothesis 5: the more attention the company pays to the government's social responsibility, the stronger the capacity for corporate sustainable development is.

\section{Model Construction}

\section{Sample Data Sources}

In recent years, an increasing number of listed companies in China have disclosed corporate social responsibility reporting and sustainability reporting, and have achieved good social repercussions. This paper selects listed tourism and commerce companies as the research subjects, and takes the listed tourism companies of $2010-2012$ as samples. This paper excludes all the ST, SST, PT companies, and companies with abnormal and missing data from the samples, and finally selects 69 listed companies as the samples of this study. Data and calculation methods described herein are mainly from GTA Information, Corporate Annual Reports, Eastmoney Network and other means.

\section{Design and Definitions of the Variables}

\section{Measurement of Corporate Social Responsibility}

On the basis of the relevant literature and after consultation with experts, and in accordance with the reality of listed tourism companies, this paper selects five dimensions for corporate social responsibility which include: corporate social responsibility to employees (X1), corporate social responsibility to customers (X2), corporate social responsibility to investors (X3), corporate social responsibility to suppliers (X4) and corporate social responsibility to government (X5). Given the limitations of the research environment, this paper uses the corporate social responsibility indicators designed by Yuqing and MA Lili (2005)[10]. The dimensions of corporate social responsibility measures are defined as follows:

$\mathrm{X} 1$ = payments to employees and cash payments for employees / revenue

$\mathrm{X} 2$ = operating costs / operating income

$\mathrm{X} 3=$ cash dividends and cash interest expense / revenue

$\mathrm{X} 4=$ accounts receivable turnover $=$ revenue / average occupancy of accounts receivable

$\mathrm{X} 5$ = (payments of taxes - refunds of taxes) / operating income

\section{Measurement of Corporate Sustainable Development}

In this paper, with reference to domestic and foreign scholars' evaluation system of corporate sustainable development capacity (in accordance with the corporate sustainable development capacity indicators designed by Su Dongwei, Wu Yangru, Liu Jian, Liu Ran and other authors[11] [12]), and in accordance with the reality and characteristics of listed tourism companies, this paper measures corporate sustainable development from the three dimensions of management capacity, solvency capacity and development capacity. Detailed specifications are shown in Table 1. 
Tab. 1 Enterprises’ sustainable development evaluation index system

\begin{tabular}{|c|c|c|}
\hline Capacity & Indicator & Calculation Method \\
\hline \multirow{4}{*}{$\begin{array}{l}\text { Management } \\
\text { Capacity }\end{array}$} & Return on Equity & Net Profit /Average Shareholders' Equity \\
\hline & $\begin{array}{l}\text { Ratio of Profit as a } \\
\text { Percentage of Sales }\end{array}$ & Net Profit / Operating Income \\
\hline & Earnings per Share & Net profit/Total Equity \\
\hline & $\begin{array}{c}\text { Total Asset } \\
\text { Turnover }\end{array}$ & Operating Revenue/ Average Total Assets \\
\hline \multirow{4}{*}{$\begin{array}{l}\text { Solvency } \\
\text { Capacity }\end{array}$} & Current Ratio & Current Assets / Current Liabilities \\
\hline & Quick Ratio & $\begin{array}{c}\text { (Current Assets - Inventory) / Current } \\
\text { Liabilities }\end{array}$ \\
\hline & $\begin{array}{l}\text { Debt to Assets } \\
\text { Ratio } \\
\end{array}$ & Total Liabilities / Total Assets \\
\hline & Equity Ratio & Debt / Equity \\
\hline \multirow{5}{*}{$\begin{array}{l}\text { Development } \\
\text { Capacity }\end{array}$} & $\begin{array}{l}\text { Increase Rate of } \\
\text { Main Business } \\
\text { Revenue } \\
\end{array}$ & $\begin{array}{c}\text { (Business Revenue of current year- } \\
\text { Business Revenue of last year)/ Business } \\
\text { Revenue of last year } \\
\end{array}$ \\
\hline & Net Profit Growth & $\begin{array}{c}\text { (Net Profit of current year - Net Profit of } \\
\text { last year)/ Net Profit of last year }\end{array}$ \\
\hline & $\begin{array}{l}\text { Owner's Equity } \\
\text { Growth Ratio }\end{array}$ & $\begin{array}{l}\text { (Owner's Equity at end of current year- } \\
\text { Owner's Equity at end of last year) / Owner's } \\
\text { Equity at end of last year }\end{array}$ \\
\hline & $\begin{array}{l}\text { Total Assets } \\
\text { Growth Rate }\end{array}$ & $\begin{array}{c}\text { (Total Assets at end of current year-Total } \\
\text { Assets at end of last year) / Total Assets at } \\
\text { end of last year }\end{array}$ \\
\hline & $\begin{array}{l}\text { Self-sustainable } \\
\text { Growth Rate }\end{array}$ & $\begin{array}{l}\text { Net Profit Margin *Total Asset Turnover * } \\
\text { Retained Earnings Rate*beginning of term } \\
\text { Equity end of term Total Assets Multiplier }\end{array}$ \\
\hline
\end{tabular}

\section{Control Variable}

Some studies (Feng Lili, Wang Jianqiong, 2011) show that company scale is a significant factor affecting the sustainable development of companies[13]. Therefore, in the study of the relationship between corporate social responsibility and corporate sustainable development, we need to have control on the scale of the company by using natural logarithm of total assets in the following analysis.

\section{Model Construction}

To test the five hypothesis set forth above, we build regression model as follows:

$$
C S D_{i t}=c+\beta_{1} X_{1 i t-k}+\beta_{2} X_{2 i t-k}+\beta_{3} X_{3 i t-k}+\beta_{4} X_{4 i t-k}+\beta_{5} X_{5 i t-n}+\beta_{6} \text { LnSize }_{i t}+\varepsilon_{i t}
$$

Wherein t represents the year (from 2010 to 2012); k represents the order of lag period, a value of 0,1 or 2; i represents serial number of company; LnSize represents the logarithmic scale of the company; CSD is a comprehensive index and consists of 13 standardized indicators added together which include management ability, solvency and development capacity etc. After taking into account that there is a certain time lag in the impact on corporate sustainable development after fulfilling corporate social responsibility, we add time lag into formula (1).

\section{Research Results and Analysis}

We can conclude from the R2 coefficient from the three regression models(Table 2) that : except for the lower regression goodness of fit of the 2010, goodness of fit of the regression equation is good in 2011 and 2012, especially in the first lag period of 2011 where R2 is 0.65 or more. And all of the 
three regression equations have passed the 0.01 significance level test.

Tab. 2 Estimate of sustainable development function coefficient

\begin{tabular}{|c|c|c|c|c|c|c|c|c|c|}
\hline \multirow{2}{*}{ Variable } & \multicolumn{3}{|c|}{2010} & \multicolumn{3}{|c|}{2011} & \multicolumn{3}{|c|}{2012} \\
\hline & Coefficient & $\mathrm{t}$ & Sig. & Coefficient & $\mathrm{t}$ & Sig. & Coefficient & $\mathrm{t}$ & Sig. \\
\hline $\mathrm{C}$ & -6.964 & -0.440 & 0.662 & -4.786 & -0.491 & 0.625 & -5.366 & -0.513 & 0.610 \\
\hline $\mathrm{X}_{1}$ & -40.370 & -3.090 & 0.003 & -19.102 & -2.337 & 0.023 & -16.296 & -1.838 & 0.071 \\
\hline $\mathrm{X}_{2}$ & -4.996 & -0.850 & 0.399 & 8.766 & 2.398 & 0.020 & 12.565 & 3.172 & 0.002 \\
\hline $\mathrm{X}_{3}$ & 24.241 & 1.009 & 0.317 & 19.258 & 1.289 & 0.202 & 28.210 & 1.741 & 0.087 \\
\hline $\mathrm{X}_{4}$ & 0.064 & 0.899 & 0.372 & 0.173 & 3.941 & 0.000 & 0.133 & 2.811 & 0.007 \\
\hline $\mathrm{X}_{5}$ & -28.286 & -1.976 & 0.053 & -22.023 & -2.477 & 0.016 & -13.967 & -1.451 & 0.152 \\
\hline Ln(Size) & 0.680 & 1.030 & 0.307 & 0.051 & 0.128 & 0.899 & -0.062 & -0.145 & 0.885 \\
\hline $\mathrm{R}^{2}$ & \multicolumn{3}{|c|}{0.313} & \multicolumn{3}{|c|}{0.653} & \multicolumn{3}{|c|}{0.565} \\
\hline F & \multicolumn{3}{|c|}{4.703} & \multicolumn{3}{|c|}{19.414} & \multicolumn{3}{|c|}{13.395} \\
\hline
\end{tabular}

From the empirical results in Table 2, we can draw the following conclusions:

Firstly, corporate social responsibility to employees has significant negative correlation with corporate sustainable development, while showing less significant negative correlation after two periods of lag. The reason may be that the selected companies' data are from 2010, when most companies had not yet come out from the financial crisis and the welfare benefits of employees were still in the recovery period.

Secondly, the variable of corporate social responsibility to customers does not pass hypothesis testing of the current period, while passing the testing with data from lag 1 and lag 2 periods, showing a significant positive correlation with the dependent variable of corporate sustainable development. The reason may be that corporate social responsibility to customers may not get rewarded in that same year, and customer acceptance and recognition of their products will take some time.

Thirdly, the variable of corporate social responsibility to investors does not pass hypothesis testing, and the variable also does not pass the testing of the model constructed with nine sample companies by Hou Tingting and Wang Jianqiong (2009). The reason may be that our selected sample companies has been established for a relatively short period of time, that the number of sample companies is also small, and that most of the sample companies are still in their early days or at difficult stages of growth. The primary task for companies at this stage is to consider the cash needs for company development strategies, and it is only at the later growth stage or maturity stage that companies will begin to consider paying more cash in return to investors or shareholders. Thus, the short-term focus on interests of investors will affect the realization of the companies' long-term development goals.

Fourthly, the variable of corporate social responsibility to suppliers does not pass the current hypothesis testing, while passing the testing with data from lag 1 and lag 2 periods, , showing a significant positive correlation with the dependent variable of corporate sustainable development. The reason may be that it takes a long time for the companies to establish enduring and mutually beneficial relations with related suppliers, and the current fulfillment of corporate social responsibility to suppliers is beneficial to the long term corporate sustainable development

Fifthly, the variable of corporate social responsibility to government only passes the hypothesis testing after lag 1 period; and contrary to the assumptions mention above, it shows a significant negative correlation with the dependent variable of corporate sustainable development, only showing weak negative correlation in the current period. The reason may be that the selected 
samples are tourism and commerce companies, and that the fulfillment of their social responsibility to the government may increase the cost of doing business and cut profits in the short run. But in the long run, the government not only can coordinate the interests of all sectors of social and economic functions, but also can create a favorable external environment for corporate development, which is good for long-term stability and development of enterprises.

Sixthly, as the control variable, the variable of company asset scale does not pass the test in the regression model, which is consistent with results obtained by Wang Jianqiong and Hou Tingting (2009). The reason may be that asset scale is represented by the total amount of assets at the end of year, and this treatment may cause data deviation because of time lag.

\section{Conclusions and Enlightenment}

The starting point of this paper is corporate social responsibility of listed tourism and commerce companies in China, and we test the impact of fulfillment of corporate social responsibility on corporate sustainable development with empirical data of 69 listed companies from 2010-2012. The fulfillment of corporate social responsibility is specifically divided into corporate responsibility to employees, to customers, to investors, to suppliers and to the government; and we find out that corporate social responsibility to employees, to customers, to suppliers and to the government have significant influence on corporate sustainable development after one period lag. While this paper only verifies that the fulfillment of responsibility to customers and suppliers has significant positive correlation with sustainable development, we can still see that fulfillment of corporate social responsibility will greatly promote future sustainable development. Some companies in China do not fulfill their social responsibility and their development doesn't seem be affected by this in the short term. That's because China's market mechanism is not yet perfect and the market mechanism does not yet play a decisive role in the allocation of resources, because the current law can not be enforced in time, and because the degree of public awareness of corporate social responsibility is relatively low. But in the long run, the market will eventually become the invisible hand, and the companies that do not fulfill their corporate social responsibility will be forced out of the market. We conclude that companies can survive and achieve sustainable development only if they take into account the interests of all parties (employees, customers, investors, suppliers, government and other stakeholders), place the long-term fundamental interests of stakeholders in an important position, and at the same time deal well with the relationship with the surrounding social environment.

\section{References}

[1]Dijken F. Corporate social responsibility, market regulation and the evidence[J]. Managerial Law,2007,49(4):141-184.

[2]Brammer S J,Pavelin S. Corporate Reputation and Social Performance: The Importance of Fit[J].Journal of Management Studies,2006,43(3):435-455.

[3]Freedman,M,B. Jaggi.. Pollution Disclosures, Pollution Performance and Economic Performance[J].The International Journal of Management Science, 1982,(10):167-176.

[4]Wang Jianqiong, Hou Tingting. Empirical study on the influence of corporate social responsibility on corporate sustainable development [J], Science \& Technology Progress and Policy, 2009, (9):94-96.

[5]Brown,T J,Dacin,P A.The Company and the Product: Corporate Associations and Consumer Product Responses[J].Journal of Marketing,1997,61:68-84.

[6]Carla,C L.Social Responsibility of the Top Ten Publicly Traded Brazilian Companies in Relation to the Amazon Rainforest[J].Social Science Electronic Publishing,2008.

[7] Shao Wenhua. Analysis of the impact mechanism of corporate social liability on corporate 
sustainable development [J]. Hubei Social Sciences, 2006,(12):119-122.

[8]Li Peilin. Study on corporate social responsibility and corporate sustainable development [J]. Modern Finance and Economics, 2006,(10):11-15.

[9]Wang Famin. Corporate social responsibility, SA800 and sustainable development [J].Enterprise Economy, 2005,(6):14-16.

[10]Chen Yuqing, Ma Lili. Empirical analysis of market reaction to listed companies' social responsibility accounting information[J]. Accounting Research,2005,(11):76-81.

[11]Su Dongwei, Wu Yangru. Econometric model and empirical analysis of sustainable development for Chinese listed companies [J].Economic Research Journal,2005, (01):106-115

[12]Liu Jian, Liu Ran. Impact of corporate social responsibility on sustainable development, based on empirical study on listed companies of iron and steel industry [J]. Soft Science, 2012,(10):104-106.

[13]Feng Lili, Lin Fang, Xu Jialin. Nature of property ownership, ownership concentration and corporate social responsibility fulfillment [J].Journal of Shanxi University of Finance and Economics,2011,(9):100-107. 